\title{
Improving Tadris Bahasa Inggris Students' Competency of Curriculum Development in Language Education through Investigating SMU Teachers' Perceptions on the Implementation of 2013 Curriculum
}

\author{
Indrawati \\ ${ }^{1}$ IAIN Syaikh Abdurrahman Siddik Bangka Belitung
}

\begin{tabular}{ll}
\hline \hline Info Artikel : \\
\hline & \\
Diterima & $: 22$ Oktober 2018 \\
Direvisi & $: 17$ November 2018 \\
Dipublish & $:$ 15 Desember 2018
\end{tabular}

Kata Kunci :

Pengajaran Praktikum

Strategi

Guru

Keywords:

Praticum Teaching

Strategies

Teacher

\begin{abstract}
ABSTRAK
Pengajaran Praktikum tidak pernah mudah bagi kebanyakan siswa. Mereka harus menjalani banyak kursus sebelum memiliki praktikum praktikum yang sebenarnya. Menyeimbangkan antara kinerja dan kompetensi akhirnya tidak sepenuhnya sepotong kue dalam hal pengajaran yang sebenarnya. Kurangnya keterampilan dalam merancang rencana pelajaran, membuat bahan ajar, dan mengelola kelas kadang-kadang menjadi hambatan besar bagi guru pre-service. Dan yang membuatnya lebih buruk adalah mereka tidak tahu benar tentang implementasi K-13 dalam mengajar bahasa Inggris di sekolah menengah. Sebagai kurikulum baru yang diterapkan, guru preservice harus berjuang untuk menerapkan kurikulum ini dengan baik dalam pengajaran mereka. Studi ini menyelidiki suara guru tentang K-13 dan strategi atau pendekatan apa yang dilakukan guru bahasa Inggris untuk mengembangkan kualitas pengajaran di kelas. Temuan menunjukkan bahwa sebagian besar guru bahasa Inggris sangat menyambut baik dalam mengimplementasikan K-13 tetapi dalam beberapa kondisi (bagi pemerintah untuk memperhatikan), seperti memberikan lebih banyak pelatihan dan kursus menjembatani untuk guru terutama di pinggiran kota, menambahkan lebih banyak buku teks gratis untuk siswa yang tidak mampu, dan begitu seterusnya.
\end{abstract}

\section{ABSTRACT}

Practicum Teaching has never been easy for most students. They have to undergo many courses before having the real practicum teaching. Balancing between the performance and competence finally is not totally a piece of cake in terms of real teaching. Lacks of skill in designing lesson plans, creating teaching material and managing classroom are occasionally become e great obstacle for pre-service teachers. And what makes it worse is they do not know well about the implementation of $K-13$ in teaching English in high schools. As a new implemented curriculum, pre-service teachers should struggle to apply this curriculum well in their teaching. This study investigates teachers' voices over K-13 and what strategies or approaches that teachers of English do to develop the quality of instruction in the classroom. Findings showed that mostly teachers of English are very welcome in implementing $K-13$ but in some conditions (for government to notice), such as providing more trainings and bridging courses for teachers especially in suburbs, adding more free text books for unprivileged students, and so on

\section{Koresponden: \\ Indrawati, \\ Email: indrawati.fr@gmail.com}

\section{Introduction}

Tadris Bahasa Inggris students of IAIN Syaikh Abdurrahman Siddik Bangka Belitung have to pass Curicululum Development in Language Education course in the fifth semester before they have Micro Teaching in the sixth semester. Those two courses are given before they do their real practicum teaching in high schools. In Curriculum Development course, they usually get some theories related to what curriculum, syllabus and lesson plan are (Kelly, 2009). The writer has done some preliminary research about this. And the writer is also the lecturer of this subject (Curriculum Development in Language Teaching) and has taught the same subject eight years in a row. Moreover, the text books of curriculum used do not provide the 
actual information about the latest curriculum, syllabus, lesson plans used in schools, either Junior or Senior high schools. That's why the students should be equipped with enough competences before doing their practicum teaching.

Although one of the objectives of joining this course is the students should be able to implement the most appropriate curriculum approaches in teaching and learning English language based on the needs of students', society and stakeholders, but they usually get difficulties in reaching this learning objectives (Zaim, 2017). There are some reasons for this. The first is the textbooks used are too theoretically and not directly applicable for the students who will do their practicum teaching in high schools(D. Ahmad, 2014). We all agree that teaching is a skill; we study the competence first and later on we do the performance. The students get the theory whenever they join Curriculum Development in Language Education but how about their performance? They will do their Micro Teaching without having enough information on how they should implement that curriculum in teaching and learning in real class (Hendriani, 2016)

The second reason is because most of the students do not have experience in teaching high schools before (Maba, 2017). Surely, it is not easy at all for them to stand in front the class and perform good language instructions (Jusnita \& Ismail, 2018). Yes, they are lack of information related to what current curriculum is implemented and how it should be implemented based on the theories they have got (Cahyati, Rachmijati, \& Supartini, 2014). The third reason is about the dynamicity of curriculum changing in our country. As we know 2013 Curriculum implemented since 2014 but before that we had gone through some curriculum shifts (Munif, 2015)

The curriculum in Indonesia has been changing and developing overtime (Darsih, 2015). Indonesia has already implemented ten curriculums known as: The 1950 curriculum, 1958, 1962, 1968, 1975, 1984, 1994, 2004, 2006 (School Based Curriculum), and the current curriculum which is used in Indonesia known as 2013 Curriculum. The 2013 curriculum has been implemented in schools in Indonesia in the last four years. 2013 curriculum is a curriculum implemented by the government to replace School-based Curriculum (SBC) or usually called Kurikulum Tingkat Satuan Pendidikan (KTSP) which has been applied for more than six (6) years and considered less effective in developing normative value because it prioritizes cognitive value (knowledge). Since the academic year 2014-2015, the Ministry of Education and Culture of the Republic of Indonesia finally decided to implement the 2013 Curriculum(Uce, 2016). Restoring character building and improving student creativity are the main reasons for the development of this curriculum.(Ashar \& Irmawati, 2016)

Having been implemented for almost four (4) years, 2013 curriculum raises many critics and obstacles. According to an Education Expert from Universitas Sebelas Maret, Prof. Dr. Furqon Hidayatullah, M.P in an interview done by Metro TV News (October 19, 2014) said that there are eight problems which make the implementation of 2013 curriculum cannot be applied smoothly. They are the difficulty of changing teacher's mindset, changing the learning process from teacher centered to student centered, low spiritual morals, law reading and research culture, the lack of information technology mastery, weakness of school administration mastery, and the tendency of teachers who emphasize more cognitive aspects. In fact, teachers should also provide the same portion on the affective and psychomotor aspects. The eighth or the last problem, there are still many teachers who do not consider teaching as life time learning. In fact, a teacher is required to increase knowledge and expand his insights, especially after the implementation of the 2013 curriculum. "The 2013 curriculum requires teachers to be more creative and innovative, meaning that teachers never stop learning," Furqon said.

There are many researches, journals and articles discussed about the 2013 Curriculum implementation. In terms of teacher's perception, the research results say that most teachers and schools are having positive attitude towards the implementation of 2013 Curriculums but there are many important things which should be highlighted. One of them is teachers' teaching approach (orientation) in enabling the students to learn English. The Decree of the Ministry of Education (Permendikbud) chapter 81a in 2013 about approach and method used in 2013 Curriculum explains that 2013 curriculum applies a five stages scientific approach namely: observing, questioning, associating or collecting information, experimenting, and networking.

The government has already tried to solve this problem. In 2016, some regulation over 2013 Curriculum were revised in order to clarify the level competence, core competence (spiritual and attitudes, knowledge and skills) based on the level of education in achieving the learning outcomes or the minimum standard competence. In Permendikbud No.23 of 2016 the government revised the standard learning assessment. It contains the learning objectives, principles, mechanisms, procedures, and instruments of assessment of learners' learning outcomes for primary and secondary school. 
But in reality, the obstacles still encounters when the teachers who are lack of methods and techniques must equip those five stages activities in their instruction and classroom assessment since they have to cover not only cognitive skill but also moral value, and character building. One example is taken from the research done by (Suryadi, 2016). He mentioned in his research finding that teachers in SMPN Bulukumba have difficulties in creating the exact assessment in integrating some skills such listening to speaking and reading to writing.

Another research done by (Andariyani \& Nurhajati, 2016) in Junior High Schools at Kediri also conclude that teacher must explore the orientation of scientific approach in order to fulfill the 2013 Curriculum recommendation which seems to be a major problem in implementing 2013 Curriculum. In addition, the same finding also got by (S. W. Sinambela, 2016) in she research about the implementation of 2013 Curriculum in SMA Negeri 1 Lubuk Pakam, the teachers do not apply the scientific approach in teaching and learning process. One of the reasons is because they do not have much time to apply it.

Based on the results of the study and discussion it can be concluded that in the implementation of the 2013 Curriculum English subjects at some junior high schools have not run optimally. This is due to the teacher's poor perception of the 2013 curriculum(D. Ahmad, 2014). Poor perceptions have an impact on the learning planning made by the teacher(S. Ahmad, 2014). That is because the negative perception of the teacher on 2013 curriculum. Some of the components in the lesson plan are not made with the highest effort too. And this was effected negatively the learning process of the students and the lack of school facilities can give the same effect to the students. Thus, the problem-solving program is needed to achieve the goals and learning outcomes. Some components in planning the lessons have not been maximally made (Ashar \& Irmawati, 2016). Therefore, efforts are needed to overcome obstacles in learning activities so that obstacles in learning activities can be overcome and the competencies of learning can be achieved.(D. Ahmad, 2014)

On the other hand, another research says the teachers' perception toward 2013 curriculum in English learning process refer to the practicality of 2013 curriculum(P. N. J. M. Sinambela, 2017) are having positive changes on students behaviour in learning process, teaching material which is adaptive and inclusive, difficulty of scientific approach implementation, lesson plan arrangement, and the freedom of teachers who are permitted to not arrange the syllabus and curriculum, The positive changes on students behaviour could be seen while the students are actively participate in learning process, especially projectbased learning. The teaching material which is quite adaptive and inclusive teaching strategies push the teachers to be more creative in utilizing the IT to access study sources, though the compulsory text books have not provided yet.

Hundreds of researches done related to fix and repair the imperfections of 2013, however most of all just focus on the teachers' perception on the 2013 Curriculum. Little attention has been paid to improve the instruction activities in developing and preparing the candidate teachers (Tadris Bahasa Inggris students) in doing their practicum teaching. Therefore, the present study attempts to fill the hidden empty space and explore the teachers' voices, orientations (approaches) and suggestion that the findings of this research later can be benefits for Tadris Bahasa Inggris students. And moreover, this kind of research has not been conducted yet in Bangka Belitung. The writer considers this problem is appropriate to investigate, remembering the benefits which can be taken from the research. Hopefully, the result of this research are not only help Tadris Bahasa Inggris students in preparing and training their practicum teaching but also can help the teachers of English in Senior High Schools in Bangka Belitung to develop and improve their instruction activities in the classroom. Research Objectives are To examine the teachers' of English perception of 2013 Curriculum and To add more knowledge of TBI Students of IAIN Syaikh Abdurrahman Siddik Bangka Belitung related to SMU Teachers' of English teaching strategies in developing instruction activities in the classroom.

\section{Method}

The population of this study is all teachers of English in senior High Schools in Bangka Belitung which have already implemented 2013 Curriculum. This study was conducted using qualitative approach. The data were collected through in-depth interview and documentation (syllabus and lesson plans). According to (Darmadi, 2011) there are some guidelines in conducting an interview, namely as follows:

1. Preparation of Interview Guidelines

Before conducting the interview, the interviewer should have a guide to be asked to the resource person. The list of questions in the interview should refer to the topic of discussion.

2. Communication In Interview

Communication is the most important component of an interview. The interviewer should be able to create a harmonious and non-monotonous atmosphere during the interview. In an interview, 
communication can be done in both formal and informal languages, with courteous and polite realms.

3. Record responses

The responses obtained during the interview can be recorded manually by the interviewer or by using a tape recorder mechanically such as using cassettes, mobile phones, and other media. Basically the recorder is mechanically more objective and efficient because it is easier to use and also reduces the risk of incomplete information obtained than using a manual recorder.

4. Initial test of interview procedure

Before doing a real interview, it helps us first test the list of questions we have prepared before. Darmadi also stated that the instruments used to collect the data should be tested before the research begins. The trials can be conducted using a small sample of the same or very similar population to be used in the study.

\section{Results and Discussion}

Here are the results of the interview done by the researcher. The interview was recorded and then analyzed based on the research problems.

\section{SMA Negeri 1 Puding Besar}

a. How is teachers' perception on the implementation of 2013 Curriculum?

I think the implementation of 2013 curriculum is good. Although, many problems happened for example, the teacher must prepare many things to the value or to score students' behavior or characters. The teacher gives each point to each value of character. The scoring criteria are not simple at all. On the other hand, 2013 Curriculum is also very good because of the teacher should know all the competences that the students have.

b. What do teachers of English teaching strategies in developing English instructions activities in the classroom?

There are some ways that I usually do in developing English instruction activities in the classroom. Firstly, I have to motivate the students so that they can speak English confidently. I often saying words like; "Come on, don't be shy", "Let's speak English", don't be afraid of making mistakes", and so on. In short, I always try to encourage them to speak English.

The second, I also create the active learning by making them work in group so that they can have interesting discussion. In grouping the students I always try to balance the member of the group in terms of their competence and ability, the fast learner students will be one group with the slow learners' student. It is hoped that they can talk more English in groups. I also make some games, puzzles and quizzes in order to attract the students' attention.

The third way is I use reward in my teaching if they can answer my questions based on the material given. I give them points if they can answer the questions correctly. The points can be saved. And these saving points might be used if they cannot reach the target score in their examination $(K K M)$. The saving points will be added to their score if they have scores lower than 70 (seventy).

\section{SMK Negeri 5 Pangkalpinang}

a. How is teachers' perception on the implementation of 2013 Curriculum?

Curriculum is undoubtedly an inseparable part of education in Indonesia. The recent curriculum has undergone several changes, among others; the newly introduced and implemented one now is called 2013 curriculum or K-13. This curriculum is made to answer the needs and challenges to improve the quality of education in Indonesia. In my opinion, the implementation of 2013 curriculum that was introduced by the government is to develop the previous curriculum.

This curriculum is very good and more effective because it brings the true goals or objectives in English teaching which is meaningfulness and communicative function and it also focuses in developing the communicative competence. So, in this case, the 2013 curriculum adopts CLT (Communicative Language Teaching). So it is expected to see the changes from teacher center to more student center. The students learn English by observing, questioning, exploring, associating, and communicating are expected to promote students to have critical thinking, analytical competence, investigation of procedure and communicative competences. So, the students learning English by activities, oral, the real task, and using the language, the concept 
of active learning, character building, and new paradigm of 2013 curriculum are very relevant to the changes of curriculum in Indonesia. In other words, the teacher can be more active and the students enjoy the learning process.

b. What do teachers of English teaching strategies in developing English instructions activities in the classroom?

It is urgent for government to better prepare the establishment of curriculum. Because I think the government should provide the sufficient training and supervision for teachers. Since not all the teachers get the chance to follow or join the training. It can be caused by limited budget from the government. And next, as I mentioned before I think it is about time allocation for English subject. I think it is more effective if teacher teach more than 3 hours in a week because we have many task to do in the classroom. As we know, we have four competences like listening, reading, speaking and writing in that limited time. And the other suggestion is for the scoring criteria is should be simplified; now it's still very complicated.

\section{SMA Negeri 1 Mendo Barat}

a. How is teachers' perception on the implementation of 2013 Curriculum?

In the current curriculum, K-13, there are good sides and bad sides. The good side is it focuses in building or educating the students' character. So, we don't just judge students from academic achievement only but also from their attitudes. Whereas if it is still KTSP first, if only 1 KD has been done, but now with the 2013 curriculum the assessment is already systematic, for example, we conduct a daily test review, then the next $\mathrm{KD}$ is just a task with the transition period. But, over time, it is also used to the current system.

b. What do teachers of English teaching strategies in developing English instructions activities in the classroom?

In this region there is already instructor training for 2013 curriculum development. But the problem is not every teacher who joins the training can do the dissemination well. As we know, considering the limited budget, only certain teachers can join the trainings. After finishing the workshop and trainings usually they should share their knowledge to their peers and colleges at school. This is what we called bridging courses or dissemination. But in reality, the dissemination usually do not run well. And the impact is only some teachers know about new policies and some changing related to how implement K-13

\section{MAN Insan Cendikia Bangka Tengah}

a. How is teachers' perception on the implementation of 2013 Curriculum?

$\mathrm{K} 13$ is a very good curriculum because it emphasizes character building .It also consists of detailed guidelines for teaching. It has warming up procedure, literacy, teaching material, tactics and observation sheets which are very useful for a teacher in giving assessment to students.

b. What do teachers of English teaching strategies in developing English instructions activities in the classroom?

We hope the time allocation can be added. Ninety minutes of learning English in a week are not enough. In addition, the practical activities where the students can practice their English actively should be added more and more so that their comprehension related to the subject learned will be increased.

\section{SMK Negeri 2 Koba}

a. How is teachers' perception on the implementation of 2013 Curriculum?

$\mathrm{K}-13$ is the latest curriculum that has been used in this Koba Vocational School No.2. K-13 is a curriculum that has provided detailed points in teaching. This curriculum simplifies teachers' job responsibilities, especially English teachers in planning learning. It distinguishes $\mathrm{K}-13$ from the previous curriculum. K-13 also prioritizes the scientific approach.

b. What do teachers of English teaching strategies in developing English instructions activities in the classroom?

Hopefully the material listed in the K13 can be balanced both theories and practices because both are crucial in the process of learning English. 


\section{SMA Negeri 3 Pangkalpinang}

a. How is teachers' perception on the implementation of 2013 Curriculum?

My view of implementing the 2013 curriculum is very good for the current learning process. In the 2013 curriculum there is no longer the CHBS method (note the book until it runs out) which was occasionally used by the teacher when teaching in class. 2013 curriculum, teachers are required to be creative and innovative so that the learning process in the classroom is fun and the material given will be easy to understand for the students. Then, to achieve success in the learning process the teacher is also required to make lesson plans $(R P P)$. The RPP used in the 2013 curriculum is also very different from the previous RPP. This can be seen from the way of creating Kompetensi Inti/KI (Core competencies), Kompetensi Dasar/KD (basic competencies), learning goals, materials, learning steps, etc. In the 2013 curriculum, character building is very concerned. In $\mathrm{K}-13 R P P$, there is already a complete attachment to support character building education for students. In short, the use of the 2013 curriculum is very useful and good to reach the 21 st century education which is better than before.

b. What do teachers of English teaching strategies in developing English instructions activities in the classroom?

To develop the students' mastery of English skills, I invite students to practice in front of the class after the material is given. This practice can be in the form of group work and pair work. They present their work using English. By doing that, it's not only to practice their speaking ability, but it is also intended students to enrich their vocabulary knowledge as well. So, it is hoped that after the material is given or taught by the teacher, they comprehend what concept of the material itself is like (the topic and the content given), then they perform it in front of the class using good English. Surely, they are still under the guidance of their English teacher. Their teacher will give precise and clear instructions. I hope the results will gradually give a positive impact on the development of their English.

Actually SMAN 3 itself basically has tried to improve the students' English ability in reading, speaking and writing. So we have been cooperated with AMINEF (American Indonesian Exchange Foundation) for the last 5 years. So we have been cooperated with AMINEF for 4 times in advance. AMINEF assigned one English Teaching Assistant (ETA) for one year to help us teaching English here. Unfortunately, we do not apply for that this year because we thought it was not effective, I mean not all of the students are motivated to learn from that (AMINEF), some students have low vocabulary mastery, so they feel a bit shy to communicate. Where as that is not the problem. It is just because our nature which is too scared to make mistakes.

Basically, the school principals have tried our best, at that moment there is also other program called English Corner and English Day, but the result didn't satisfying enough. Besides that, there are also Chinese and Japanese classes. So some students are motivated to get involved, courageous to communicate, and there is a bit effect, but I mean it didn't affect the whole students yet may be because it is from outside the school, the activities are most likely a game, so they are different from the activity in a regular class.

I mean it would take much time, while if the students get involved in game-like activities they are likely to be all out, but all of that is still not enough for us. If they get involved in gamelike activities, they will be enthusiastic and excited. But, their national exam score are not satisfying enough. That is the obstructions. This year, the school has allocated the additional time as a strategy by the adding of Muatan Lokal (local subject). But, Lintas Minat are not totally effective, because there are also some other languages. As another option, every class needs to get involved in Lintas Minat 3 hours in a week.

\section{SMK Negeri 1 Simpangkatis}

a. How is the teachers' perception on the implementation of curriculum 2013?

Answer: the teachers have many perceptions about the implementation of the 2013 English curriculum. I divided their perception about the 2013 English curriculum to the major point relate to the curriculum: the subject material, the teaching learning process and the evaluation. The teacher creativity is necessary to the teaching learning process more interesting and the purpose of 2013 curriculum are building students character, having good spiritual and social attitudes, ready to face the global era.

b. What are teachers of English teaching strategies in developing English instructions activities in the classroom? 
Answer:

- Teachers should have a creative idea

- Teachers make the students speak more English in the classroom

\section{Conclusion}

Teachers of English in some school in Bangka Regency, Pangkalpinang, and Central Bangka agree that $\mathrm{K}-13$ is a very good curriculum since it covers the whole education. It evaluates not only the students' competences, performances but considering the students' character building. Fortunately not all teachers have the chances to join the trainings and workshops which develop the teachers' skills, competencies, and knowledge about how to plan the lesson in $\mathrm{K}-13$, how to evaluate the students, and the strategies, methods, and techniques in facilitating the students in learning. At the beginning of its launched, the character value should be equipped in every lessons and subject, and it was frustrating for teachers in evaluating and scoring the students. But some changes and policies in curriculum issued by the government make the scoring system becomes easier. But again, the dissemination, bridging courses related to the new policies and changes in designing the lesson and doing the instruction in the classroom still haven't been implemented well.

Based on the problems found during the implementation of $\mathrm{K}-13$, teachers of English agree that the study length or duration for English subject must be added. So next academic year, it is hoped that the government will add the learning hour for English subject. The teachers also hope that the government will facilitate more trainings and workshops for teachers to develop their competencies and performances in creating a well implemented lesson plan and evaluation. If English subject considers less important than mathematics, science and Bahasa Indonesia, then it shouldn't be nationally tested.

\section{Referensces}

Ahmad, D. (2014). Understanding the 2013 curriculum of English teaching through the teacherse and policymakersee perspectives. International Journal of Enhanced Research in Educational Development (IJERED), 2(4), 6-15.

Ahmad, S. (2014). Problematika kurikulum 2013 dan kepemimpinan instruksional kepala sekolah. Jurnal Pencerahan, 8(2).

Andariyani, N., \& Nurhajati, D. (2016). The Implementation Of Teaching English Based On Curriculum 2013 Applied By An English Teacher Of Junior High School. English Education: Journal Of English Teaching And Research, 1(2), 9.

Ashar, A., \& Irmawati, I. (2016). The Implementation of the 2013 Curriculum of English at SMKN 1 Bantaeng: an Evaluative Study. Elt Worldwide, 3(2), 156-169.

Cahyati, S. S., Rachmijati, C., \& Supartini, N. (2014). Analysis of English High School Teacher Management as the Implementation of Curriculum 2013. Eltin Journal, Journal of English Language Teaching in Indonesia, 2(1).

Darmadi, H. (2011). Metode penelitian pendidikan. Bandung: Alfabeta.

Darsih, E. (2015). Indonesian Efl Teachers'perception On The Implementation Of 2013 English Curriculum. English Review: Journal of English Education, 2(2), 192-199.

Hendriani, S. (2016). Permasalahan Guru Bahasa Inggris Dalam Mengimplementasikan Kurikulum 2013 Di SLTA Kabupaten Tanah Datar. Ta'dib, 18(1), 67-75.

Jusnita, N., \& Ismail, A. (2018). Implementasi Kurikulum 2013 Dalam Pembelajaran Bahasa Inggris Di SMP Kota Ternate. Edukasi, 16(1).

Kelly, A. V. (2009). The curriculum: Theory and practice. New York. Sage.

Maba, W. (2017). Teacher's perception on the implementation of the assessment process in 2013 curriculum. International Journal of Social Sciences and Humanities, 1(2), 1-9.

Munif, D. N. (2015). Implementasi Kurikulum 2013 Mata Pelajaran Bahasa Inggris di SMP Negeri 9 Madiun. An-Nuha: Jurnal Kajian Islam, Pendidikan, Budaya \& Sosial, 2(2), 269-283. 
Sinambela, P. N. J. M. (2017). Kurikulum 2013 dan Implementasinya dalam Pembelajaran. Generasi Kampus, 6(2).

Sinambela, S. W. (2016). The Implementation of Curriculum 2013 in English Teaching-Learning Process at SMA Negeri 1 Lubuk Pakam. Medan. UNIMED.

Suryadi, R. (2016). The Implementation of Assessment in Curriculum 2013 in English Subject of SMPN Bulukumba. Journal of English Education, 1(2), 111-117.

Uce, L. (2016). Realitas Aktual Praksis Kurikulum: Analisis terhadap KBK, KTSP dan Kurikulum 2013. Jurnal Ilmiah Didaktika: Media Ilmiah Pendidikan Dan Pengajaran, 16(2), 216-229.

Zaim, M. (2017). Implementing scientific approach to teach English at senior high school in Indonesia. Asian Social Science, 13(2), 33-40. 